\title{
DYNAMIC ESTIMATING THE KARST TUNNEL WATER INRUSH BASED ON MONITORING DATA DURING EXCAVATION
}

\author{
PRIČAKOVANA DINAMIKA VDORA VODE V PREDORE NA \\ PODLAGI MERITEV MED NJIHOVO GRADNJO
}

\author{
KANG Xiaobing $^{1 *}$, LUO Sheng ${ }^{2}$, XU Mo ${ }^{1}$, ZHANG Qiang $^{1} \&$ YANG Yanna ${ }^{1}$
}

\begin{abstract}
UDC 556.3:624.191(510)

Kang Xiaobing, Luo Sheng, Xu Mo, Zhang Qiang \& Yang Yanna: Dynamic estimating the karst tunnel water inrush based on monitoring data during excavation

The tunnel water gushing has long been a difficult hydrogeological problem, especially in karst areas. It affects the entire process of tunnel construction, operation and maintenance. In view of the complex disaster-causing mechanism and difficult quantitative predictions of water inrush, several theoretical methods are adopted to realize dynamic assessment of water inrush in the progressive process of tunnel construction. According to a survey conducted in the Zoumaling tunnel near Chongqing, China, $62 \%$ of its total length, e.g., $1525 \mathrm{~m}$ is associated with karst (including a fault fracture zone). On the basis of collecting real-time monitoring data about water inrush in the excavated section of the Zoumaling tunnel, a fuzzy data analysis method has been used to analyze the content of seven common ions in the inflow water, which makes it possible to classify the groundwater types and to establish the hydrogeological model of the tunnel site. In order to forecast the possibility and quantity of water inrush, it is essential to accurately model the groundwater system spatially. The preliminary forecasting result about untapped section reveals a small possibility of a sudden water inflow disaster and $35,000 \mathrm{~m}^{3} / \mathrm{d}$ water inflow, which is close to the ultimately measured quantity of water. This study provides a theoretical reference for the prediction of water inrush during tunnel construction, and the main characteristic of this study is reflected in the real-time prediction of tunnel water inrush according to actual tunnel inflow of excavated sections. This approach can be applied in similar situations for the prediction of tunnel water inrush in other karst regions.
\end{abstract}

Key words: karst region, tunnel water inrush; dynamic estimate; fuzzy cluster analysis.
Izvleček

UDK 556.3:624.191(510)

Kang Xiaobing, Luo Sheng, Xu Mo, Zhang Qiang \& Yang Yanna: Pričakovana dinamika vdora vode $v$ predore na podlagi meritev med njihovo gradnjo

Pojav vdiranja vode v predore je že dolgo časa poznana težava, še posebej na kraških območjih. Pojavlja se med celotno gradnjo predorov, njihovo uporabo in vzdrževanjem. Za proučevanje potencialnega pojava nesreč in težavnega napovedovanja količine vdora vode je bilo preizkušenih več različnih teoretičnih metod. Te omogočajo oceno dinamike vdora vode med celotnim procesom gradnje predorov. Pri predoru Zoumaling v bližini mesta Chongqing (Kitajska) približno $62 \%$ dolžine predora (1525 m) poteka na območju krasa in čez prelomna območja. Na podlagi $\mathrm{v}$ realnem času zbranih podatkov o vdorih vode v izkopanih odsekih predora Zoumaling se je naredila analiza mehkih množic. Ta je bila uporabljena za analizo sedmih v vodi najbolj značilnih ionov in je omogočila razvrstitev podzemne vode $\mathrm{v}$ različne skupine, s tem pa izdelavo hidrogeološkega modela neposredne okolice predora. Za analizo verjetnosti vdora vode in njene možne količine je izdelava natančnega modela vodonosnika zelo pomembna. Prvi rezultati, ki se nanašajo na en še nedokončan odsek, kažejo na majhno možnost nenadnega vdora vode. Največja možna dnevna količina vdora je ocenjena na 35.000 m3, kar je blizu najvišje izmerjene dnevne količine dotoka. Pričujoča raziskava vzpostavlja teoretično podlago za napoved vdora vode $\mathrm{v}$ času gradnje predora, glavna posebnost pa je napoved vdora $v$ realnem času na podlagi izmerjenega dotoka v že izkopanih odsekih predora. Predstavljen postopek in napovedi, ki jih omogoča, se lahko uporabijo v podobnih primerih tudi na drugih kraških območjih.

Ključne besede: kraško območje, vdor vode $\mathrm{v}$ predore, pričakovana dinamika, analiza mehkih množic.

${ }^{1}$ State Key Laboratory of Geohazard Prevention and Geoenvironment Protection, Chengdu University of Technology, Chengdu, 610059, PR China, e-mail: kangxiaobing09@cdut.cn, xm@cdut.edu.cn, zhangq@cdut.edu.cn, yangyanna@cdut.cn

${ }^{2}$ College of Engineering, Sichuan Normal University, Chengdu 610071, PR China, e-mail: 1847044883@qq.com

* Corresponding author 


\section{INTRODUCTION}

According to the "World Karst Aquifer Map" scaled $1: 40,000,000,14.7 \%$ of the Earth's surface entirely or partly consists of karst carbonate rocks (Goldscheider \& Chen 2017). China has one of the most extensive karst occurrences, with an area of $3,463,000 \mathrm{~km}^{2}$, accounting for $30 \%$ of its territory, including exposed karst, covered karst (under loose sediments), and buried karst (under non-soluble bedrock) (Yuan et al. 1991). Karst areas have the most developed carbonate deposits of the southwest mountains, such as Yunnan, Guizhou, Sichuan, and Hubei Province. Due to the characteristics of karst geology and terrains, it is always difficult to control water inrush into tunnels under construction in karstic terrain (Radulović 2013).

Construction of tunnels in karst areas may cause drying-up of springs and losses of base-flow in mountain streams (Vincenzi et al. 2013). Groundwater inrush into tunnels is one of the most unpredictable problems in tunnel construction due to the complexity of karst development and distribution. For underground engineering, the risk source is hard to precisely determine and tackled, which imposes difficulty to the ground inspection and construction (Li et al. 2015). This may bring about a potential hazard for personal injury and may lead to project delays and huge economic losses (Wang et al. 2016; Handong et al. 2017). For instance, in the Yesanguan tunnel of Yichang-Wanzhou Railway, water inrush occurred in "DK124 + 602" karst tunnels on 5 August 2007. The peak flow rate reached $1.5 \times 10^{5} \mathrm{~m}^{3} / \mathrm{h}$, which caused that 10 workers died unfortunately and the equipment and machinery in the tunnel was seriously damaged (Jiang 2017).

Therefore, it is essential to be able to accurately predict the water inrush that is likely to occur into a tunnel. Over the last few decades, due to the progressive increase of tunnel construction in the world (Song et al. 2006; Perello et al. 2013), a certain amount of effort has been dedicated to develop methods to forecast inrush into tunnels. Common water gushing calculation method is shown in Tab. 1 (Zhou \& Li 2000). Meanwhile, there is more work to be done to understand water inrush disasters fully. These formulas generally requires a series of related parameters about the formation permeability coefficient $(\mathrm{K})$, water depth, tunnels affect width and so on. The quality and accuracy of these input data affect the reliability of the prediction results tremendously (Heuer 1995; El Tani 2003; Raymer 2005; Perrochet 2005; Kolymbas \& Wagner 2007). Once the parameters can be accurately determined and its calculation accuracy more refined. Hence it is necessary to improve the quality of the data input for the forecast of water inrush of tunnels in karst areas.

In addition to the formula mentioned in Tab. 1, there are related factors analysis, numerical calculation method, nonlinear theory and other methods to predict the tunnel water inrush (Li et al. 2013). Both the normal tunnel water inrush, and the maximum tunnel water inrush, are great uncertainty and have a large difference with the actual water inrush so far, yet no mature theory and proven accurate calculation.

This paper develops such an approach through a case study in Chongqing, China. It begins with a detailed introduction to the tunnel site hydrogeological and water gushing disaster. Then, the field water gushing monitoring and water chemical clustering analysis method are taken to study the tunnel inrush. Finally, forecast tunnel water inrush accurately based on the identification of the groundwater system in tunnel site. This method is proposed to estimate water inrush of tunnel, especially in construction stage.

Tab. 1: Common water discharge calculation method and description.

\begin{tabular}{|l|l|l|}
\hline Method & Applicable conditions & Accuracy \\
\hline $\begin{array}{l}\text { Rainfall infiltration } \\
\text { method }\end{array}$ & $\begin{array}{l}\text { Suitable for shallow burial depth mountain tunnel, also } \\
\text { applies to the karst area }\end{array}$ & $\begin{array}{l}\text { May forecast macroscopic and approximate normal } \\
\text { tunnel water discharge }\end{array}$ \\
\hline $\begin{array}{l}\text { Runoff modulus } \\
\text { calculation method }\end{array}$ & $\begin{array}{l}\text { Suitable for mountain tunnel through one or more surface } \\
\text { water catchment areas, also applies to the karst area }\end{array}$ & $\begin{array}{l}\text { May forecast macroscopic and approximate normal } \\
\text { tunnel water discharge }\end{array}$ \\
\hline $\begin{array}{l}\text { Runoff depth } \\
\text { calculation method }\end{array}$ & $\begin{array}{l}\text { Suitable for mountain tunnel through one or more surface } \\
\text { water catchment areas, also applies to the karst area }\end{array}$ & $\begin{array}{l}\text { May forecast normal tunnel water discharge, but it } \\
\text { is an approximate quantity }\end{array}$ \\
\hline $\begin{array}{l}\text { Groundwater } \\
\text { dynamics method }\end{array}$ & Suitable for almost all kinds of conditions & $\begin{array}{l}\text { May forecast normal tunnel water discharge. Once } \\
\text { the parameters can be accurately determined, its } \\
\text { calculation accuracy more refined. }\end{array}$ \\
\cline { 2 - 3 } & $\begin{array}{l}\text { May forecast maximum tunnel water discharge. } \\
\text { Once the parameters can be accurately } \\
\text { determined, its calculation accuracy more refined. }\end{array}$ \\
\hline Analogy method & $\begin{array}{l}\text { Applicable in the proposed tunnel close to a similar } \\
\text { project, which has similar hydrogeological conditions. }\end{array}$ & $\begin{array}{l}\text { May forecast approximate normal tunnel water } \\
\text { discharge and maximum tunnel water discharge. }\end{array}$ \\
\hline $\begin{array}{l}\text { Isotope tritium } \\
\text { method }\end{array}$ & Suitable for mountain tunnel and hillside tunnel. & $\begin{array}{l}\text { A relatively accurate method, but the isotopes data } \\
\text { is difficult to obtain }\end{array}$ \\
\hline
\end{tabular}




\section{SITE DESCRIPTION}

The Zoumaling tunnel is a crucial section of the road between Shizhu City and Wanzou City (Fig. 1). The tunnel crosses the Mt. Fangdou mountain anticline with a maximum terrain elevation of $1250 \mathrm{~m}$ a.s.l. The south and north entrances of the tunnel are marked with labels K46+614 and K49+077 on the map (Fig. 2), respectively, with a total length of the tunnel of $2463 \mathrm{~m}$. The tunnel elevation is about $690 \mathrm{~m}$ a.s.l. and the overburden thickness is nearly $400 \mathrm{~m}$. The tunnel cuts through the Fangdou mountain anticline at a right angle. The tunnel crosses the biggest fault (F18) close to the position of borehole ZK2-4 (Fig. 2). Due to intense fracturing in the rock mass karst phenomena, including cavities were developed in the core of the anticline. Prior to construc-

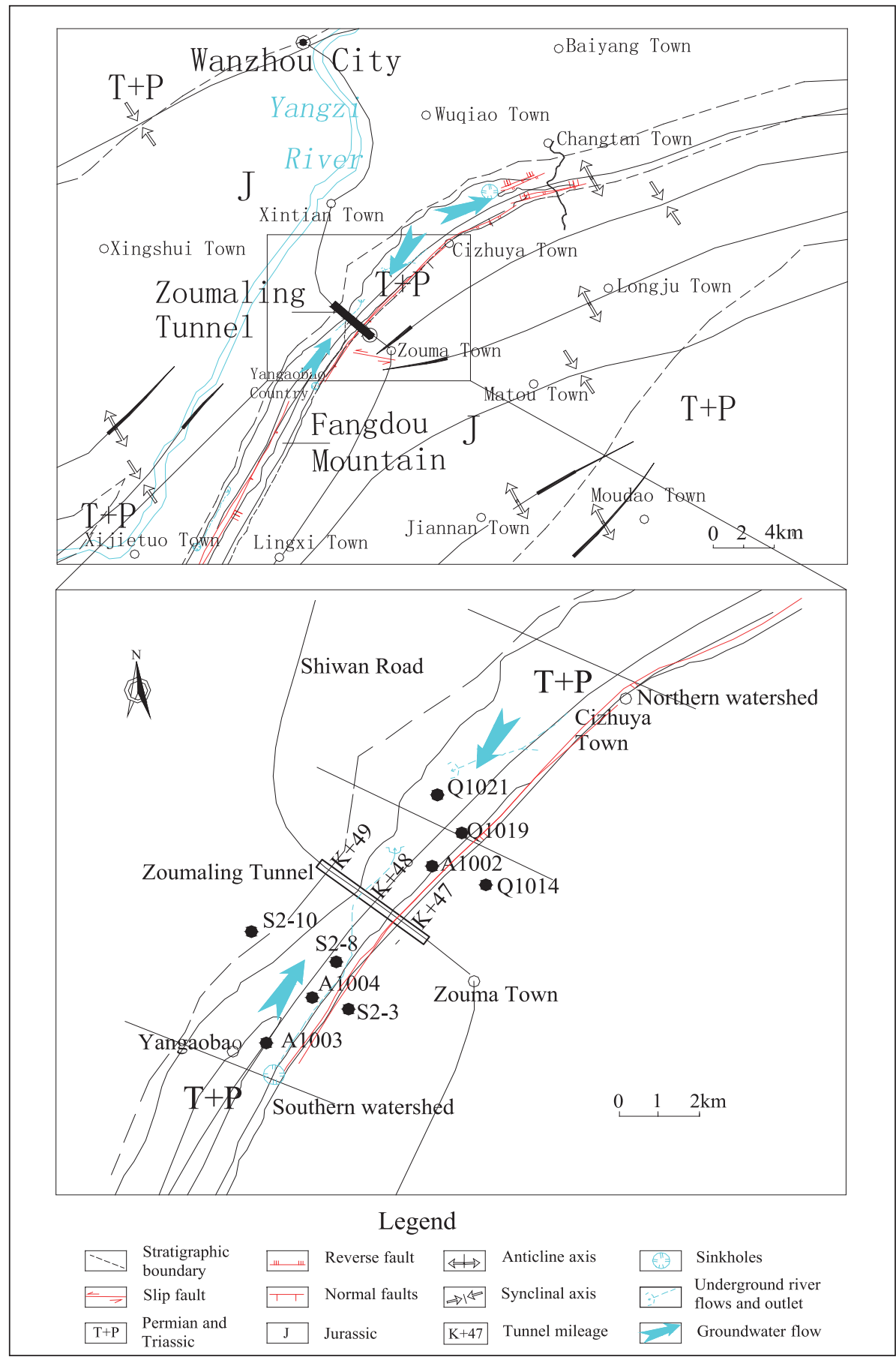

Fig. 1: Geological map and location of water samples of Zoumaling tunnel. 


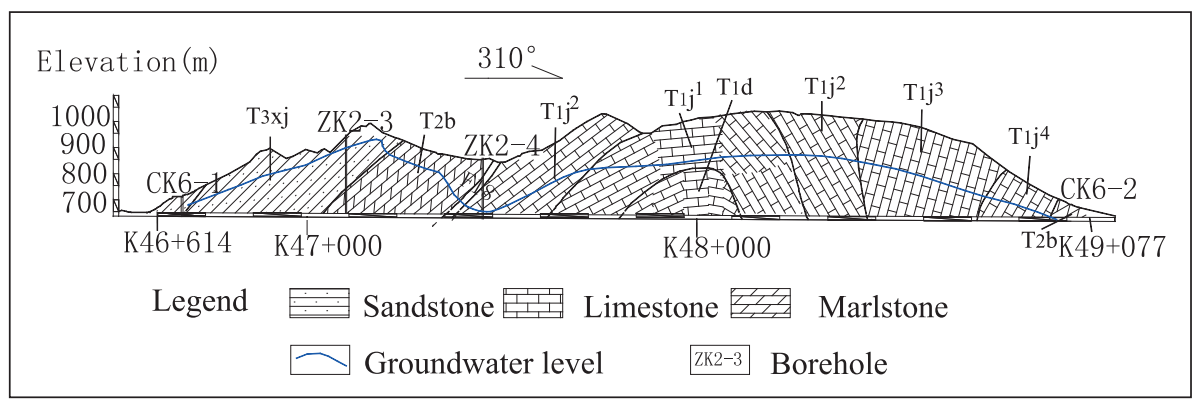

Fig. 2: Section profile along the tunnel.

tion, an exploration hole ZK2-3 was drilled down to the tunnel level. The water level in this borehole was encountered at $906.2 \mathrm{~m}$ a.s.l., more than 225 meters above the tunnel level. This confirmed that the planned tunnel would encounter karst water under pressure.

Before building underground structures in karst areas, it is necessary to carefully evaluate the extent of the karst landforms, including epikarst and underground karst (Day 2004; Xeidakis et al. 2004; Casagrande et al. 2005; Knez et al. 2008; Zini et al. 2015).The Fangdou mountain anticline is an isolated hydrogeological unit which is flanked on its eastern and western sides by impervious sandstone and mudstone units. Both sides of the anticlinal mountain form cliffs and steep slopes. The core of the anticline is composed of limestone $\left(\mathrm{T}_{1} \mathrm{~d}\right.$, $\mathrm{T}_{1} \mathrm{j}, \mathrm{T}_{2} \mathrm{~b}$ ) which forms valleys and depressions of various forms and sizes (Fig. 2). Except for evaporation, all precipitation in the region of the anticline above the tunnel infiltrates into the underground. Hence the recharge of the groundwater in the anticline is very good. In addition to the structural features caused by a variety of tectonical events, the neotectonic activity in this region is also very important. There are many karst forms in this area, including springs, caves, sinkholes, underground rivers, depression, and the karst water recharge runoff and discharge conditions are very complex. Therefore, all these factors make the carbonate rocks in the Fangdou mountain anticline favorable for karst development.

The Yangze River valley, $18 \mathrm{~km}$ north of tunnel is the regional base level at $150 \mathrm{~m}$ a.s.l. As the average elevation of the tunnel base is about $540 \mathrm{~m}$ higher than the regional base level, the tunnel is located in the vertical alternating zone of karst water, so the hydrological conditions in this area are of a complex type.

\section{MONITORING AND ANALYSIS OF THE TUNNEL WATER GUSHING}

The construction of Zoumaling tunnel began on January $8^{\text {th }}, 2004$ from both entrances simultaneously. Due to the complex geological formations and groundwa-

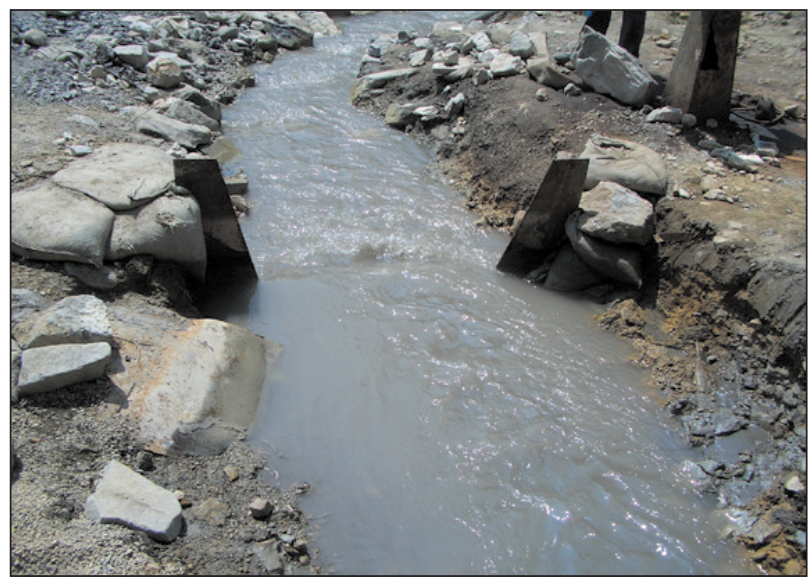

ter inrush problems (Fig. 3), the excavation progress was very slow.

In May, 2004, a long term program started to moni-

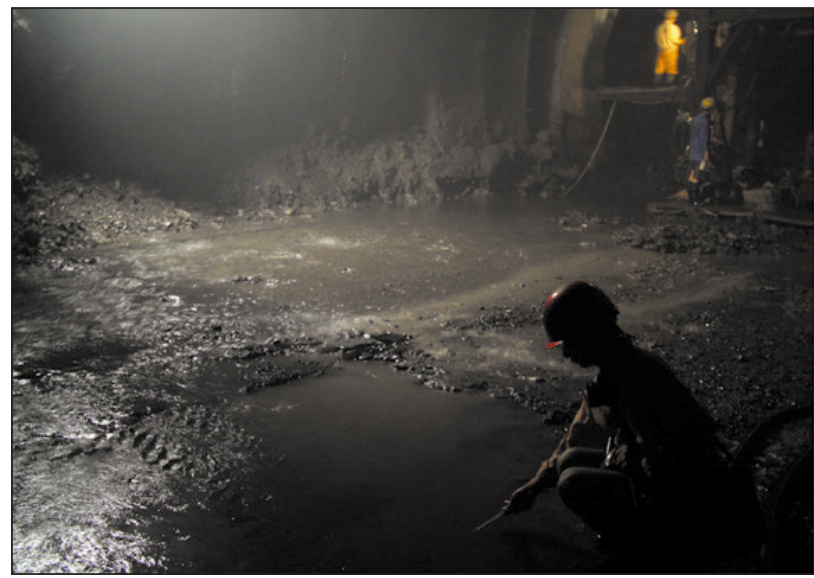

Fig. 3: Two photos of Zoumaling tunnel water inrush. Left: trapezoidal weir, located at tunnel entrance. Right: tunnel water inrush located at K47+350 (Photos: Q. Zhang). 
tor the water chemical composition, head pressure, etc. of inrush points of the tunnel, during the tunnel excavation process with help of in-situ monitoring equipment simultaneously at both sides of the tunnel. Fig. 4 shows the total daily water gushing quantities at both tunnel entrances from May $13^{\text {rd }}$ to September $23^{\text {rd }}$, 2004; the tunnel was completed in late 2005. The curve shows clearly the variation of gushing over time during the tunnel excavation.

Before May $27^{\text {th }}$, the tunnel was excavated in $\mathrm{T}_{3} \mathrm{xj}$, sand-shale rock, containing groundwater in bedrock fis-

Tab. 2: Average monthly inrush per lithological unit during the period May to September of 2004.

\begin{tabular}{|l|c|c|c|c|c|}
\hline \multicolumn{1}{|c|}{ Date $($ month $)$} & $\mathbf{5}$ & $\mathbf{6}$ & $\mathbf{7}$ & $\mathbf{8}$ & $\mathbf{9}$ \\
\hline Inrush $\left(\mathrm{m}^{3} / \mathrm{d}\right)$ & 5985 & 4307 & 8249 & 10066 & 12396 \\
\hline $\begin{array}{l}\text { Stratum in tunnel } \\
\text { driving face }\end{array}$ & $\mathrm{T}_{3} \mathrm{xj}$ sandrock & $\mathrm{T}_{2} \mathrm{~b}$ marlite & Lamina marlite & $\begin{array}{l}\text { Ending of } \mathrm{T}_{2} \mathrm{~b} \text { stratum, } \\
\text { fault broken zone of } \mathrm{F}_{18}\end{array}$ \\
\hline
\end{tabular}
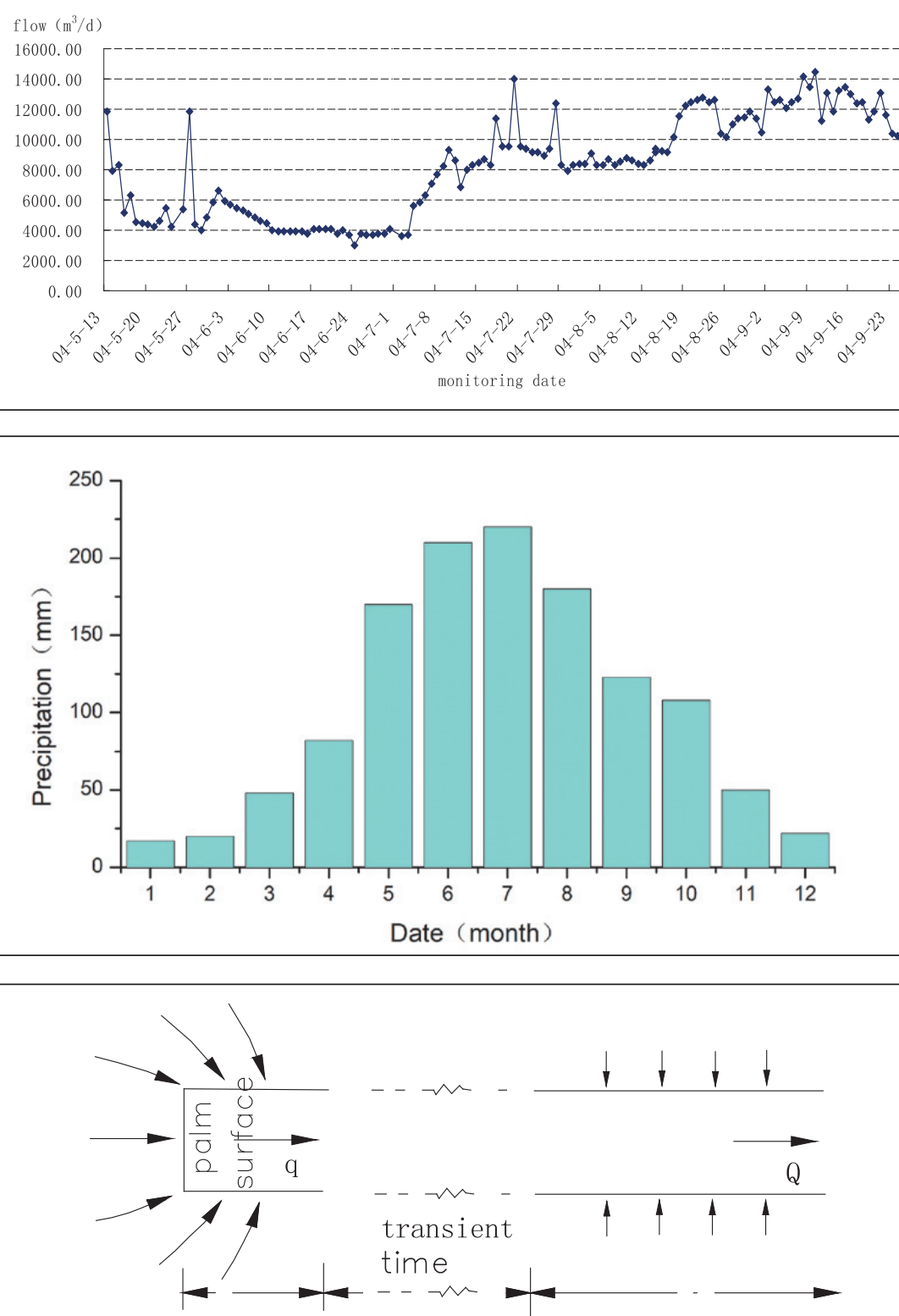

driving working surface initial water discharge long-term and stability condition
Fig. 4: Total volume of daily water discharge monitored at both tunnel entrances during the excavation process until September $23^{\text {rd }}, 2004$. The tunnel was completed in late 2005.

Fig. 5: Monthly rain fall measured in 2004 of Wanzhou.

Fig. 6: Schematic view of initial water inrush and steady-state water inrush. 
sures. The water inrush rapidly decreased to a stable level. When the tunnel reached the $\mathrm{T}_{2} \mathrm{~b}$ unit at K47+013.5 on May $28^{\text {th }}$, a large gushing occurred at the unit contact (Fig. 4). The maximum inrush increased to almost $12,000 \mathrm{~m}^{3} / \mathrm{d}$, then rapidly reduced, and stayed stable between 4,300 and $5,200 \mathrm{~m}^{3} / \mathrm{d}$. At K47+194, on July $4^{\text {th }}$, the groundwater inrush increased gradually because the rock surrounding the tunnel is tectonically shattered, reaching a volume of $14,000 \mathrm{~m}^{3} / \mathrm{d}$ on July $21^{\text {st }}, 2004$, then gradually decreasing again. On August 17 ${ }^{\text {th }}, 2004$, the tunneling reached the broken fault zone F 18 and water inrush began to increase to an average daily quantity of over $12,000 \mathrm{~m}^{3}$ in September. Based on the daily monitored inrush data, the average inrush values were calculated and listed in Tab. 2 .

Fig. 5 shows the rainfall histogram for 2004 for the Wanzhou area where a high precipitation period in June and July is clearly marked. The peak in the tunnel water inrush in July (Fig. 4) can be correlated with this rainy period. But after this period, the water inrush still showed an upward trend. So there was not a clear relationship between the tunnel water inrush and rainfall. The water inrush quantity seems to be correlated as well with the actual geological characteristics. The reason of larger initial water gushing at the start of the tunnel excavation is the water flow into the tunnel from the tunnel driving face and the rock surrounding the tunnel (Fig. 6) (Heuer 1995) due to a higher water pressure in the tunnel driving face. The groundwater volume stored in the rock mass at the tunnel site before excavation is larger than after. The water stored in the discontinuities in the rock mass around the tunnel before the excavation is the source of the initial water gushing. This inrush decreases after the excavation as the rock mass was drained during the excavation (Wang 1994). So the water gushing into the tunnel decreases after an initial large volume and then stabilizes gradually.

The forecast result of tunnel water inrush is 12500 $\mathrm{m}^{3} / \mathrm{d}$ using the groundwater dynamics method, and it is $12400 \mathrm{~m}^{3} / \mathrm{d}$ using the precipitation method according to a detailed survey report (Sichuan Coalfield Geology ... 2003). This differed greatly from the water monitoring values. This may be due to non-consideration of the geological conditions in the tunnel zone and the parameters of the drainage area, and/or due to unreasonable infiltration coefficient values used. For the $\mathrm{T}_{1} \mathrm{j}$ limestones which are exposed nearly $1525 \mathrm{~m}$ in the tunnel no exploration and testing data were available, so the applicability of the groundwater dynamics method was restricted.

\section{WATER CHEMICAL COMPOSITION CLUSTER ANALYSIS}

For a proper prediction of the water inrush into the tunnel, we must know the hydrogeological conditions and the groundwater spatial model (Li 1988; Zhou et al.
2015). For this purpose, we carried out a detailed hydrogeological investigation in the project area, including

Tab. 3: Hydrochemistry analysis of the water samples. Water samples from nine spring points ( $x_{1}$ to $\left.x_{9}\right)$ around the tunnel and six water samples from the different tunnel discharge ( $x_{10}$ to $\left.x_{15}\right)$.

\begin{tabular}{|c|c|c|c|c|c|c|c|c|}
\hline \multirow{2}{*}{ Sampling Point } & \multirow{2}{*}{ Room No. } & \multicolumn{7}{|c|}{ Main ion content in water (unit $\mathrm{g} / \mathrm{l}$ ) } \\
\hline & & $\mathrm{CO}_{3}^{2-}$ & $\mathrm{HCO}_{3}^{-}$ & $\mathrm{Cl}^{-}$ & $\mathrm{Ca}^{2+}$ & $\mathrm{Mg}^{2+}$ & $\mathrm{SO}_{4}^{2-}$ & $\mathrm{K}^{+}+\mathrm{Na}^{+}$ \\
\hline Q1014 & $x_{1}$ & 0 & 0.104 & 0.002 & 0.032 & 0.010 & 0.052 & 0.010 \\
\hline Q1019 & $x_{2}$ & 0 & 0.360 & 0.008 & 0.116 & 0.010 & 0.041 & 0.009 \\
\hline Q1021 & $x_{3}$ & 0 & 0.368 & 0.004 & 0.137 & 0.010 & 0.079 & 0.004 \\
\hline A1002 & $\mathrm{x}_{4}$ & 0 & 0.204 & 0.007 & 0.064 & 0.007 & 0.033 & 0.010 \\
\hline A1003 & $x_{5}$ & 0 & 0.175 & 0.003 & 0.058 & 0.003 & 0.017 & 0.004 \\
\hline A1004 & $x_{6}$ & 0.005 & 0.191 & 0.006 & 0.058 & 0.021 & 0.079 & 0.012 \\
\hline $\mathrm{S} 2-3$ & $x_{7}$ & 0.003 & 0.170 & 0.003 & 0.074 & 0.003 & 0.052 & 0.002 \\
\hline S2-8 & $\mathrm{x}_{8}$ & 0 & 0.253 & 0.003 & 0.084 & 0.005 & 0.041 & 0.011 \\
\hline S2-10 & $x_{0}$ & 0 & 0.245 & 0.001 & 0.079 & 0.003 & 0.021 & 0.007 \\
\hline $\mathrm{K} 46+860$ & $x_{10}$ & 0 & 0.107 & 0.001 & 0.024 & 0.004 & 0.006 & 0.009 \\
\hline K46+927 & $x_{11}$ & 0 & 0.107 & 0.001 & 0.024 & 0.004 & 0.014 & 0.012 \\
\hline $\mathrm{K} 47+014$ & $x_{12}$ & 0 & 0.172 & 0.003 & 0.082 & 0.015 & 0.156 & 0.020 \\
\hline $\mathrm{K} 47+063$ & $x_{13}$ & 0 & 0.175 & 0.001 & 0.066 & 0.009 & 0.071 & 0.008 \\
\hline K47+194 & $\mathrm{x}_{14}$ & 0 & 0.266 & 0.001 & 0.085 & 0.005 & 0.048 & 0.017 \\
\hline $\mathrm{K} 47+220$ & $x_{15}$ & 0 & 0.285 & 0.001 & 0.105 & 0.009 & 0.083 & 0.011 \\
\hline
\end{tabular}


a large number of water chemical tests. The test results were analyzed with fuzzy mathematics.

\section{FUZZY CLUSTER ANALYSIS}

Water samples from nine spring points and underground river along the tunnel and six water samples from the tunnel gushing were examined (Fig. 1). The total of 15 water samples underwent a cluster analysis. For each water sample seven ions' values were determined $\left\{\mathrm{CO}_{3}{ }^{2}\right.$ , $\left.\mathrm{HCO}_{3}^{-}, \mathrm{Cl}^{-}, \mathrm{Ca}^{2+}, \mathrm{Mg}^{2+}, \mathrm{SO}_{4}^{2-}, \mathrm{K}^{+}+\mathrm{Na}^{+}\right\}$(Tab. 3).

With the absolute value subtraction formula (1) we calculated the fuzzy similarity relation between the samples. If $\mathrm{c}=0.01$ we obtain the fuzzy similarity matrix $\boldsymbol{R}$ (Huang 1999; Ye \& Li 2005; Fan et al. 2006).

$r_{i j}= \begin{cases}1 & i=j \\ 1-c \sum_{k=1}^{m}\left|x_{i k}-x_{j k}\right| & i \neq j\end{cases}$

When we make the value of $\mathrm{c}$ meet $0 \leq r_{i j} \leq 1$ 。
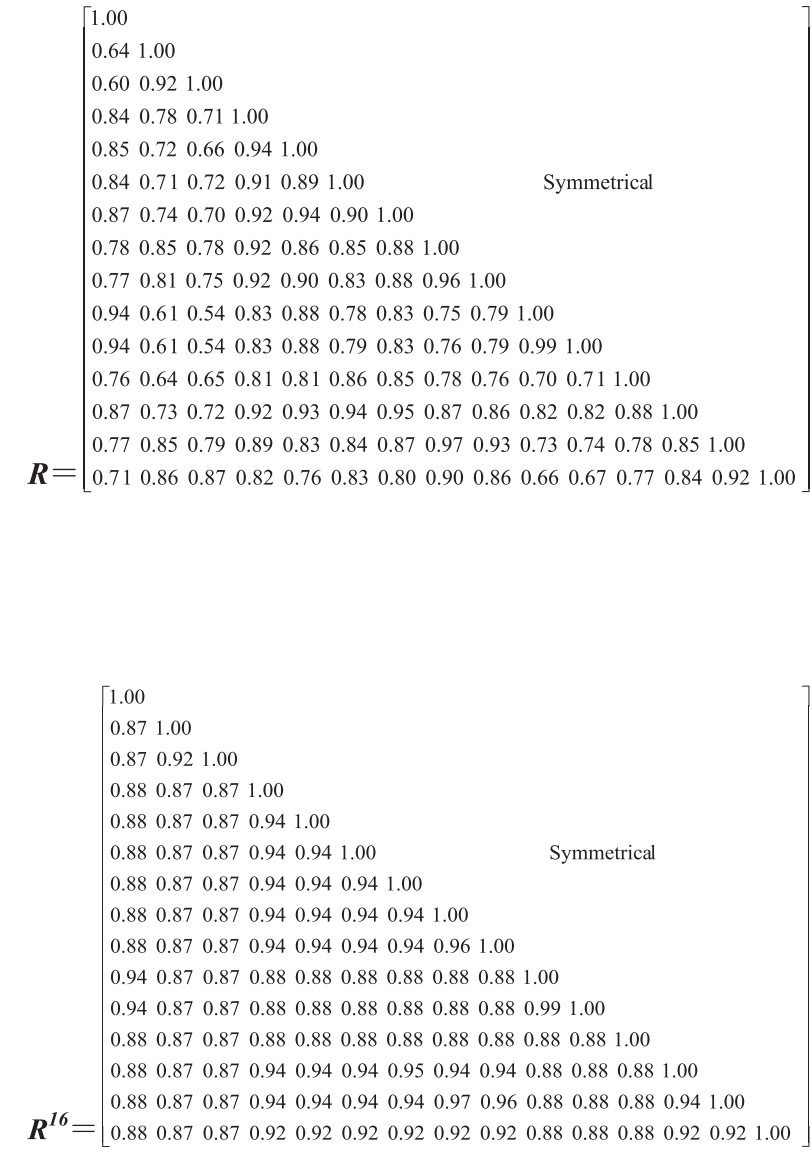

When $\boldsymbol{R}^{32}=\boldsymbol{R}^{16} \cdot \boldsymbol{R}^{16}$, then $\boldsymbol{R}^{16}$ is the fuzzy equivalence matrix, using the truncated matrix equation (2) of the fuzzy matrix, for different values of $\lambda$. So a number of classifications are the outcome. We can then plot the clustering (Fig. 7).

$\substack{i j \\ \lambda \in[0,1]}_{(\lambda)}^{(\lambda)}= \begin{cases}1 & r_{i j} \geq j \\ 0 & r_{i j}<j\end{cases}$

\section{CLUSTER RESULT ANALYSIS}

Fig. 7 shows that, clusters $x_{10}$ and $x_{11}$ have a correlation coefficient $r_{i j}{ }^{\circ}=0.99$, which shows that these two have the best correlation. Then sample $x_{1}$ with a value $r_{i j}{ }^{\circ}=0.94$ joins the cluster. Furthermore samples $x_{8}$ and $x_{14}$ form a cluster 2nd class, with a correlation coefficient $r_{i j}^{\circ}=0.97$, then $x_{9}$ joins this cluster with a $r_{i j}{ }^{\circ}=0.96 ; x_{7}$ and $x_{13}$ form a cluster 3 rd class, with a correlation coefficient $r_{i j}^{\circ}=0.95$, etc. Finally, when $x_{2}$ and $x_{3}$ join, with a correlation coefficient $r_{i j}^{\circ}=0.87$, all indicators classify as a combination of classes and the fuzzy clustering is completed.

Between the locations $\mathrm{K} 46+800$ and $\mathrm{K} 47+220$ the tunnel is located in the $\mathrm{T}_{2} \mathrm{~b}$ rock type, near fault $\mathrm{F}_{18}$, where a highly permeable fractured zone is present. As there are karstic dissolution holes and cracks, the problem of water burst is very important in this part of the tunnel with many spring points in both tunnel walls. The correlation coefficient between K46+860 $\left(x_{10}\right)$ and K46+927 $\left(x_{11}\right)$ of $r_{i j}{ }^{\circ}=0.99$ is very high. At both sampling points, there is $\mathrm{Fe}_{2} \mathrm{O}_{3}$ crusting at the spring point. This proves that the two water samples came from the same fissures or karst holes. Similarly, the second and the third class of correlations with $r_{i j}^{\circ}>0.92$ also have a strong relevance. The correlation coefficient of the three classes with $r_{i j}^{\circ}=0.88$ are assumed to be in the same groundwater system, but supposedly with a weak hydraulic connection. With a value of $r_{i j}{ }^{\circ}=0.87, \mathrm{Q} 1019\left(x_{2}\right)$ and Q1021 $\left(x_{3}\right)$ cluster with the other water samples. Fig. 1 shows that these two points are located at the groundwater division, which means that they may belong to different groundwater systems, though they also have a good correlation.

According to the analysis of water samples taken during the site investigation and tunnel construction phase, the degree of mineralization of groundwater in this area is low, between $0.173 \mathrm{~g} / \mathrm{l}$ and $0.362 \mathrm{~g} / \mathrm{l}$, with an average of $0.254 \mathrm{~g} / \mathrm{l}$; the $\mathrm{pH}$ is between 6.9 and 8.3 , with an average of 7.7. It shows that all karst water in this region has similar recharge, runoff and gushing conditions. Due to the large permeability of the rock masses in this area, the water flow distance from the infiltration area to the gushing area in the tunnel is short, leading to a fast groundwater cycle. The groundwater chemistry is mainly dominated by $\mathrm{HCO}_{3}-\mathrm{Ca}$, followed by $\mathrm{HCO}_{3}-\mathrm{SO}_{4}-\mathrm{Ca}-\mathrm{Mg}$ and $\mathrm{HCO}_{3}-\mathrm{SO}_{4}-\mathrm{Ca}$.

Based on the analysing of water chemical composition by cluster method in Zoumaling tunnel, we can 


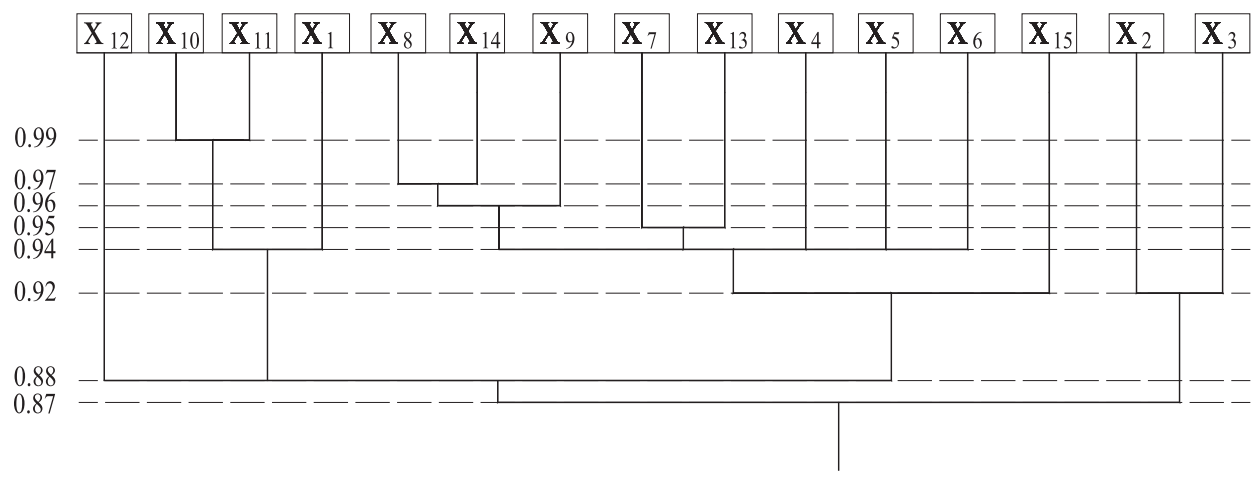

Fig. 7: Fuzzy clustering result. The left column of data between 0.87 and 0.99 in the figure means the correlation coefficient for each cluster.

divide and analyse groundwater system of tunnel site accurately, and it is the foundation to forecast tunnel water inrush.

\section{FORECASTS OF TUNNEL WATER INRUSH}

In the static estimate of the design stage, the water inrush is determined through using common water gushing calculation method. Then by using real-time monitoring data including water gushing, groundwater specimen even lithologic characteristics during the excavation of tunnel, dynamic estimate of water inrush can be realized in the progressive process of tunnel construction. Ultimately we can use the method of groundwater runoff modulus to calculate the tunnel water inrush.

The values for this parameter $M$ (modulus of runoff) were taken from the 1:200,000 regional hydrogeological report of Wanxian and Zhongxian County (Sichuan Geological Bureau ... 1981, 1984). According to the exposed position of the strata, the topography, and in combination with the runoff conditions in the hydrogeological units, the values of groundwater runoff modulus during the dry season are estimated as follows (Meng \& Lei 2003):

$\mathrm{J}_{2} \mathrm{~s}$ and $\mathrm{J}_{1} \mathrm{zh}$ formation (Jurassic) $\mathrm{M}=0.75\left(\mathrm{l} / \mathrm{s} \bullet \mathrm{Km}^{2}\right)$;

$\mathrm{T}_{3} \mathrm{xj}$ formation (Upper Triassic) $\mathrm{M}=0.75\left(\mathrm{l} / \mathrm{s} \bullet \mathrm{Km}^{2}\right)$;

$\mathrm{T}_{2} \mathrm{~b}$ formation (Middle Triassic) $\mathrm{M}=3.96\left(\mathrm{l} / \mathrm{s} \bullet \mathrm{Km}^{2}\right)$;

$\mathrm{T}_{\mathrm{j}} \mathrm{j}$ formation (Lower Triassic) $\mathrm{M}=6.0\left(\mathrm{l} / \mathrm{s} \bullet \mathrm{Km}^{2}\right)$.

The aquifer thickness is calculated above the tunnel axis, and the area is measured from 1:50,000 geological maps.
Then we use the following formula: $\mathrm{Q}=86.4 \cdot \mathrm{M} \bullet \mathrm{F}$ (Jiang 1991; Ministry of Railway ... 2004) to calculate the volume of groundwater inrush.

In the formula: $\mathrm{Q}=$ value of groundwater inrush $\left(\mathrm{m}^{3} / \mathrm{d}\right)$;

$\mathrm{M}=$ modulus of runoff $\left(1 / \mathrm{s} \bullet \mathrm{km}^{2}\right)$;

$\mathrm{F}=$ area of the concerned unit $\left(\mathrm{km}^{2}\right)$.

The result is shown in Tab. 4 and shows that the value of groundwater inrush calculated with help of the underground runoff modulus is almost $3.5 \times 10^{4} \mathrm{~m}^{3} / \mathrm{d}$ during the dry season.

The total volume of natural groundwater inrush during the dry season is $12,370 \mathrm{~m}^{3} / \mathrm{d}$ as calculated by the atmospheric precipitation infiltration method and groundwater dynamics method in the detailed survey report (Sichuan Coalfield Geology ... 2003) of the tunnel, which is a relatively small value, due to the fact that the watershed area was not correctly defined, which lead to a smaller catchment area. The Zoumaling tunnel construction was completed in late 2005. During the construction, no large caves and underground rivers were discovered. After the construction of the tunnel, the actual average water inrush from the tunnel was $31,000 \mathrm{~m}^{3} / \mathrm{d}$. Our forecast results according to the ground hydrogeological survey of almost $3.5 \times 10^{4} \mathrm{~m}^{3} / \mathrm{d}$ was very close to the monitoring data. So the difference between the actual monitoring data and the forecasted value with the method proposed in this paper is very

Tab. 4: Groundwater inrush calculated with help of the runoff modulus methods during the dry season.

\begin{tabular}{|l|c|c|c|}
\hline Stratum & $\begin{array}{c}\text { Area } \\
\left(\mathrm{m}^{2}\right)\end{array}$ & $\begin{array}{c}\text { Underground runoff modules } \mathrm{M} \\
\left(\mathrm{l} / \mathrm{s} \bullet \mathrm{km}^{2}\right)\end{array}$ & $\begin{array}{c}\text { Value of natural groundwater resources } \\
\text { during dry season }\left(\mathrm{m}^{3} / \mathrm{d}\right)\end{array}$ \\
\hline $\mathrm{T}_{\mathrm{ij}}$ & $44.9 \times 10^{6}$ & 6.00 & $2.3 \times 10^{4}$ \\
\hline $\mathrm{T}_{2 \mathrm{~b}}$ & $25.4 \times 10^{6}$ & 3.96 & $0.87 \times 10^{4}$ \\
\hline $\mathrm{T}_{3 \times \mathrm{j}}{ }^{\mathrm{J}} \mathrm{J}$ & $40.4 \times 10^{6}$ & 0.75 & $0.26 \times 10^{4}$ \\
\hline total & $110.7 \times 10^{6}$ & 10.71 & $3.5 \times 10^{4}$ \\
\hline
\end{tabular}


small. This was in agreement with the field observation that the tunnel water inrush during the wet period is nearly three times larger than during the dry period.

The tunnel was built in 2005, and the tunnel water inrush has not been found so far by building the corresponding size drainage channel on the basis of accurately predicting the water inflow.

\section{CONCLUSION}

Tunnel water inrush forecast is a complex issue. The volume of water inrush is controlled by topography, lithology, geological structure, the local meteorological and hydrological conditions, and many other factors. It is a subject that should be researched and explored constantly with field monitoring data, and combined with advanced technology and mathematical methods.

From this tunnel water inrush forecast evaluation it is concluded that a variety of methods should be utilized, combined with an inventory of the hydrogeological conditions in the survey area. Identify its complex of hydrogeology, runoff and gushing conditions, which is the most basic work to predict the tunnel water inrush. Only do this we can forecast and calculate the tunnel water inrush. Secondly, it is recommended to use a variety of methods to improve the prediction accuracy when to predict the tunnel water inrush. Finally, the forecast of tunnel water inrush is a dynamic processes, the actual value observed during the construction stage should be used to revise the calculation parameters during the design stage.

\section{ACKNOWLEDGMENTS}

Much of the work presented in this paper was supported by the National Natural Science Foundation of China (Grant No. 41202213), and the State Key Laboratory of Geohazard Prevention and Geoenvironment Protection
(Grant No. SKLGP2013Z003). The authors would like to express appreciation to the reviewers for their valuable comments and suggestions that helped to improve the quality of the paper.

\section{REFERENCES}

Casagrande, G., Cucchi, F. \& L. Zini, 2005: Hazard connected to railway tunnel construction in karstic area: applied geomorphological and hydrogeological surveys.- Natural Hazards and Earth System Science, 5, 2, 243-250. DOI: 10.5194/ nhess-5-243-2005

Day, M.J., 2004: Karstic problems in the construction of Milwaukee's deep tunnels.- Environmental Geology, 45, 6, 859-863. DOI:10.1007/s00254-0030945-4

El Tani, M., 2003: Circular tunnel in a semi-infinite aquifer.- Tunnelling and Underground Space Technology, 18, 49-55. DOI: 10.1016/S0886-7798(02)001025

Fan, Z.C., Chen, J.S. Dong, H.Z. \& X. Zhao, 2006: Applying fuzzy clustering method to study leakage of dyke.- Rock and Soil Mechanics, 7, 1214-1218. DOI: 10.3969/j.issn.1000-7598.2006.07.040

Goldscheider, N. \& Z. Chen, 2017: World Karst Aquifer Map 1:40,000.- BGR, IAH, KIT \& UNESCO. [Online] Available from: https://www.kit.edu/kit/english/pi_2017_174_new-world-karst-aquifer-map. php [accessed February 4th 2019].

Handong, C., Guangli X., Noriyuki, Y., Zhang, Y., Pola, L. \& W. Jifengu. 2017: Risk assessment of water inrush in karst tunnels based on two-class fuzzy comprehensive evaluation method.- Arabian Journal of Geosciences, 10, 7, 179. DOI: 10.1007/s12517-0172957-5

Heuer, R.E., 1995: Estimating rock tunnel water inflow.- In: Williamson, G.E. \& I.M. Gowring (eds.) Proceedings : 1995 Rapid Excavation and Tunneling 
Conference, $18^{\text {th }}-21^{\text {th }}$ June, San Francisco, Littleton, Colo.: Society for Mining, Metallurgy, and Exploration, Inc., 41-60.

Huang, J.Y., 1999: Fuzzy Set and Application.- Ningxia People Education Press, Yinchuan, 90-111.

Jiang, H., Lang L., Xiaoli, R., Mingyang, W., Yuanpu, X. \& Z. Zhicheng, 2017: Model test to investigate waterproof-resistant slab minimum safety thickness for water inrush geohazards.- Tunnelling and Underground Space Technology, 62, 35-42. DOI:10.1016/j.tust.2016.11.004

Jiang, J., 1991: Tunnel of engineering geology.- Beijing: China Railway Publishing House, 199-229.

Knez, M., Slabe, T., Šebela, S. \& F. Gabrovšek, 2008: The largest karst cave discovered in a tunnel during motorway construction in Slovenia's Classical Karst (Kras). Environmental Geology, 54, 4, 711-718. DOI: $10.1007 /$ s00254-007-0840-5

Kolymbas, D. \& P. Wagner, 2007: Groundwater ingress to tunnels - The exact analytical solution.- Tunnelling and Underground Space Technology, 22, 23-27. DOI: 10.1016/j.tust.2006.02.001

Li, L.P., Lei, T., Li, S.C., Xu, Z.H., Xue, Y.G. \& S. Shi, 2015: Dynamic risk assessment of water inrush in tunnelling and software development.- Goemechanics and Engineering, 9, 1, 57-81. DOI:10.12989/ gae.2015.9.1.057

Li, S.C., Zhou, Z.Q., Li, L.P., Xu, Z.H., Zhang, Q.Q. \& S.S. Shi, 2013: Risk assessment of water inrush in karst tunnels based on attribute synthetic evaluation system.- Tunnelling and Underground Space Technology, 38, 50-58. DOI: 10.1016/j.tust.2013.05.001

Li, X., 1988: Hydrogeochemistry.- Nuclear Press, Beijing, 207-223.

Meng, Y. \& M. Lei, 2003: The advance and suggestion for the study on discharge rate in karst tunnel gushing.- Carsologica Sinica, 12, 287-292. DOI: 10014810(2003)04-0287-06

Ministry of Railway of The People's Republic of China, 2004: Code for Hydrogeology investigation of railway engineering.- China Railway Publishing House, Beijing, 49-52.

Perello, P., Baietto, A., Burger, U. \& S. Skuk, 2013: Excavation of the Aica-Mules pilot tunnel for the Brenner base tunnel: information gained on water inflows in tunnels in granitic.- Rock Mechanics and Rock Engineering, 47, 3, 1049-1071. DOI: 10.1007/ s00603-013-0480-x

Perrochet, P., 2005: Confined flow into a tunnel during progressive drilling: an analytical solution.- Ground Water, 43, 6, 943-946. DOI: 10.1111/j.17456584.2005.00108.x

Radulović, M.M., 2013: A new view on karst genesis.-
Carbonates and Evaporites, 28, 4, 383-397. DOI: 10.1007/s13146-012-0125-2

Raymer, J.H., 2005: Groundwater inflow into hard rock tunnels: a new look at inflow equations.- In: Hutton, J.D. \& W.D. Rogstad (eds.) 2005 Proceedings -Rapid Excavation and Tunneling Conference, June 2005, Seattle, Littleton, Colo.: Society for Mining, Metallurgy, and Exploration, Inc., 457-468.

Sichuan Coalfield Geology 137 General Team, 2003: Zoumaling tunnel detailed engineering geological survey of Chongqing Shizhu - Wanzhou road Zouma Xintian section $(\mathrm{K} 46+614 \sim \mathrm{K} 49+077)$, 20-23.

Sichuan Geological Bureau 208 Geological Team, 1981: 1:200,000 regional hydrogeological report of Zhongxian County, 136.

Sichuan Geological Bureau Nanjiang Hydrogeology Brigade, 1984: 1:200,000 regional hydrogeological report of Wanxian County, 129.

Song, W.K., Hamm, S. \& J. Cheong, 2006: Estimation of groundwater discharged into a tunnel.- Tunnelling and Underground Space Technology, 21, 3-4, 460. DOI:10.1016/j.tust.2005.12.098

Vincenzi, V., Gargini, A., Goldscheider, N. \& L. Piccinini, 2013: Differential Hydrogeological Effects of Draining Tunnels Through the Northern Apennines, Italy.- Rock Mechanics \& Rock Engineering, 47, 3, 947-965. DOI: 10.1007/s00603-013-0378-7

Wang, J., 1994: Discussion on Outflow Calculation in Tunnel.- Journal of the China Railway Society, 16, 4, 110-115.

Xeidakis, G.S., Torok, A., Skias, S. \& B. Kleb, 2004: Engineering geological problems associated with karst terrains: their investigation, monitoring, and mitigation and design of engineering structures on karst terrains.- Bulletin of the Geological Society of Greece, 36, 4, 1932-1941. DOI:http://dx.doi. org/10.12681/bgsg.16679

Wang, Y., Jing, H, Yu, L., Su, H. \& N. Luo, 2016: Set pair analysis for risk assessment of water inrush in karst tunnels.- Bulletin of Engineering Geology and the Environment, 7, 1-9. DOI:10.1007/s10064-0160918-y

Ye, H., Chen, J. \& X. Li, 2005: Application of Water Quality Fuzzy Cluster and Environmental Isotope in Detect Seepage Access in a Dike.- Geotechnical Investigation and Surveying, 1, 22-25.

Yuan, D., Zhu, D., Weng, J., Zhu, X., Han, X., Wang, X., Cai, G., Zhu, Y., Cui, G. \& Z. Deng, 1991: Karst of China.- Geological Publishing House, Beijing, 1.

Zhou, D. \& Li, Q. 2000: Methods of prediction the tunnel water discharge.- Geotechnical Investigation and Surveying, 4, 18-32. 
Zhou, Z., Li, S., Li, L., Shi, S. \& Z. Xu, 2015: An optimal classification method for risk assessment of water inrush in karst tunnels based on grey system theory.- Goemechanics and Engineering, 8, 5, 631-647. DOI:10.12989/gae.2015.8.5.631
Zini, L., Calligaris, C. \& F. Cucchi, 2015: The challenge of tunneling through Mediterranean karst aquifers: the case study of Trieste (Italy).- Environmental Earth Sciences, 74, 281-295. DOI: 10.1007/s12665015-4165-5 